\title{
DESCRIPTION OF THE AUTOMATIC AND EXHAUST-STEAM INJECTOR.
}

By Mr. A. SLATER SAVILL, of Manchester.

The almost universal adoption of the Injector for the purpose of feeding steam boilers renders any improvement in its working a matter of very general interest to engineers. A contrivance that goes far towards perfecting the action of the injector is the "split nozzle," the joint invention of Messrs. Davies, Hamer, and Metcalfe, which it is more particularly the object of the present paper to describe.

The very extensive use of the ordinary lifting injector, by which the supply of feed-water is lifted from below the level of the injector itself, has developed not only its advantages but also its disadvantages. For starting a lifting injector to work, such as that shown in Fig. 1, Plate 20, it is necessary, after turning on the water, to withdraw slightly the steam spindle A, allowing a small quantity of steam to rush through the injector. This jet clears the nozzles, and draws along with it the air from the water pipe, thereby causing a partial vacuum, which raises the feed-water into the condensing chamber or nozzle B. The steam spindlo A may then be fully opened, and the injector will work, the supply of feedwater being regulated to suit. This manipulation for starting is required in all ordinary lifting injectors, although it is not so apparent in those with closed overflow; but even with these the small quantity of steam must first be turned on in order to lift the water up to the injector, and the larger quantity of steam must be admitted afterwards for the regular working. If therefore the injector happens to fail whilst working, the steam must be shut off, and the foregoing manipulation must be gone through in order to 
start it to work again. In most instances this means constant attendance on the injector while at work, and forms the chief disadvantage attending its use.

Automatic Injector.-The "split nozzle," shown in Figs. 2 and 3, Plates 20 and 21, entirely obviates the above disadvantage; and its adoption renders the injector perfectly automatic in starting itself to work again after an interruption. The nozzle $\mathrm{N}$ is split up longitudinally for rathor more than half its longth from its lower extremity where the bore is smallest; the loose half forms a flap, which is binged to the fixed half by a pin joint, from which it hangs freely. When the injector is not at work, the flap hangs open, and thus presents a rery large area of passage for the exit of steam. Consequently when steam is turned on, no matter how quickly, it flows through the injector with little or no resistance, and draws along with it the air from the feed-pipe, thus lifting the water. When the water reaches the condensing chamber $C$, the steam is immediately condensed, a stronger vacuum is formed (exactly as in ordinary injectors), and the flap is sucked inwards, forming then to all intents and purposes an ordinary solid nozzle, through which the water is delivered into the delivery nozzle, and thence into the boiler. This simple contrivance renders the injector perfectly automatic in re-starting; for should the working fail, the flap falls open, allowing the free escapo of the steam, and as a consequence the water is again lifted to the condensing chamber, a vacuum is obtained, the flap is again sucked inwards, and the instrument resumes work; all this occurs in far less time than it takes to describe.

Through the adoption therefore of the flap or split nozzle, the injector will re-start itself without manipulation; and whether placed above or below the level of the feed-water, it will immediately start work as soon as the boiler steam is turned fully on, and this may be done either quickly or slowly. The first starting is so simple that the instrument cannot be mismanaged: it is only necessary to turn on the steam and the water, either of them first, and the ease and rapidity with which the injector starts are remarkable. The great advantage of an automatic re-starting injector is 
especially apparent where there is much vibration, as in the case of marine and locomotive boilers, agrieultural and traction engines, \&c. For marine boilers the ordinary injector has practically been a failure, owing primarily to its "giving out" or failing in a rough sea; and when this happened, it required manipulating to start it again. This diffeulty is entirely removed by the split nozzle, as it immediately re-starts itself automatically.

Exhaust-Steam Injector.-The object for which the split nozzle was specially designed is for working an injector by means of exhaust steam only. With exhaust steam at atmospheric pressure, the injector is enabled by this means to feed a boiler working at 75 lbs. pressure per sq. inch; and at a higher pressure, if the feed-water be at a very low temperature. For feeding boilers at higher pressures than $75 \mathrm{lbs}$., a special contrivance, worked by live steam, is attached to the exhaust injector; the economy is then exactly the same as if this special contrivance were not used. (See discussion, pages 183-4.)

The arrangement for working with exhaust steam is shown in Figs. 5 to 8, Plate 22. In Figs. 5 and 7 are shown longitudinal sections of the split nozzle, and Figs. 6 and 8 are cross sectione. In both cases the flap is shown in its two positions, namely open and shut.

The steam nozzle in the exhaust injector is of very large bore, and the spindle $S$ inside it is a fixture. The receiving or condensilfy nozzle is also of a rather different make from those used for live steam. The splitting of this nozzle is carried out in exactly the same manner as previously described. There is a projection $\mathrm{P}$ inside the casing of the injector, which forms a stop for the flap, allowing it to open only a certain distance, as it is not necessary that the free area at any point of the nozzle should exceed the largest bore of the flap, namely that at the hinge.

The action of the exhaust injector is exactly similar to that of the automatic re-starting injector; but the exhaust injector requires to be fixed always below the level of the feed-water. The water and exhaust steam being turned on, either of them first, mingle together and escape freely through the enlarged nozzle. Condensation takes place, and a slight vacuum is formed, into which the exhaust steam 
and water are drawn in quantities sufficient to form immediately a very strong vacuum. The flap is thereby sucked inwards, narrowing the nozzle to its normal size, and the injector works, delivering the water into the boiler in the ordinary way.

In the case of the exhaust injector, the property of re-starting automatically is of particular value. Most engines work irregularly, in consequence of the load being sometimes heavier and at other times lighter. When the heary load is suddenly removed, as is often the case in saw-mills \&c., the engine at once gains speed, the governor throttles or altogether shuts off the steam, and there is probably insufficient steam passing through the exhaust pipe to keep the injector supplied, so that it stops by drawing in air through the open end of the exhaust pipe; but directly the engine gets its steam again, the injector re-starts of itself. It works quite as well with the engine running empty as if heavily loaded; all it wants is steam unmixed with air.

For taking the exhaust steam to the injector, the main exhaust pipes are not tampered with in any way; a branch pipe is merely taken off at some convenient part for connecting to the injector. Fig. 4, Plate 21, shows the method of taking off the branch from some vertical portion of the main exhaust pipe; and it can be similarly taken off from a horizontal portion. It will be noticed mat for the working of the injector it is not required that the main exhaust pipe should in any way be throttled; in fact the larger the pipe, the better for the injector. The other connections are similar to those of an ordinary injector. 


\section{Discussion.}

The PRESIDENT said no one had worked more with injectors than Mr. Robinson; and he was sure the members would be glad to hear what he had to say on this paper.

Mr. Jorn Rosinson feared his knowlodge of this subject was getting rather rusty. When the injector was first introduced into this country, he attended closely to all its details, and naturally took much greater interest in the progress of its development than he had done since it had become more fully matured; he had therefore to confess to a certain amount of ignorance as to some of the uses to which it had been applied. It would be observed that the paper was divided into two parts: it first described the automatic injector, and next an injector working by exhaust steam. The split nozzle or flap was stated to be a contrivance whereby the large amount of steam required in the first instance for exhausting the pipes of air, and so lifting the feed-water up to the injector, was allowed to pass without any restriction; and practice had proved that this was so. On the other hand he would call attention to a statement on p. 168, in which, when speaking of the ordinary injector described in the first instance, the author said that the manipulation necessary for starting the injector to work again when it was once stopped involved in most cases constant supervision of the injector while at work. Upon that question he should like to know what was the experience of locomotive engineors, as to how much attention was actually given by the driver of a locomotive to the ordinary injector in order to prevent its failing, in consequence of its being stopped by shunting or by any other vibration which would naturally cut off the supply of water.

The great interest of the paper seemed to him to be in regard to the use of exhaust steam for the purpose of feeding water into the boiler. For this purpose it had been stated that the injector with the split nozzle or hanging flap was very well adapted: in fact, he believed the use of exhaust steam was the object for which the split nozzle had been originally invented; and for this purpose it was 
required that the injector should be placed below the level of the feed-water, which in most cases was easily accomplished. On the other hand it appeared that, with exhaust steam at atmospherio pressure, the injector would only feed a boiler up to 75 lbs. pressure. Therefore for locomotive work, in which he himself was chiefly concerned, it became unavailable, unless there were some special appliance added to it for enabling it to overcome the difficulty. On that particular point he should be glad to be further informed, because in the paper: it was merely stated on p. 169 that for feeding boilers at higher pressures than $75 \mathrm{lbs}$. a special contrivance, worked by live steam, was attached to the exhaust injector; and from that statement the deduction was made that the economy was exactly the same as if this special contrivance were not ased. He could infer what was meant by that statement; but in this connection he thought the author had not taken sufficient credit for the considerable economy, whether in a locomotive or in any other high-pressure engine, derived from using simply waste or exhaust steam for supplying feed-water to the boiler. That advantage of the exhaust-steam injector he thought wanted bringing out a little more strongly; and he should be glad to hear the author's views as to the economy so obtained. He concluded that the addition of live steam to the exhaust steam, where the boiler pressure was higher than $75 \mathrm{lbs}$, meant that it was then necessary to give a "fillip" to the exhaust steam by means of live steam, in order to get the necessary velocity of the current to penetrate the boiler against the pressure of the steam. Upon that point he should much like to be enlightened, as well as with respect to the actual economy in the arrangement when the waste steam only was necessary for feeding the boilers. To feed boilers above $75 \mathrm{lbs}$. pressure, it appeared a low tomperature of feedwater was required, which did not often exist in this country; and of course it conld readily be understood that, the lower the temperature of the feed-water, the higher might be the pressure in the boiler into which the injector had to force the water.

Mr. T. BuDworth Sharp said the subject of the utilisation of exhaust steam by an injector was a particularly interesting one, 
both from a scientific and from a commercial point of view, because all exhaust steam that was returned into a boiler by the injector represented an absolute gain of power, or more correctly a recovery of it in such a form that it conld be used over again. An exhauststeam injector working into a high-pressure boiler, or even the working of an ordinary injector, was somewhat paradoxical, and the action was still less easy to explain in connection with the complications of Mr. Sellers' self-adjusting injector and Mr. Gresham's self-acting pet-cock. There appeared to be no loss except from radiation or possibly leakage; and while it appeared extraordinary that water should by such means be caused to enter the boiler, it was evident that it did enter.

The exhaust injector, though very ingenious, had in his opinion one great defect in not being available at all for the chief use for which it was wanted, namely for feeding locomotives, for which injectors were principally employed. If the exhaust-steam injector were applied on a locomotive, it was found that another injector working with live steam was requisite to give the current a "kick-up" on its way to the boiler; and consequently in its application to locomotives the exhaust-steam injector became nothing more than a feed-water heater. He believed 70 lbs. was the very utmost boilerpressure that this injector could force against; and to do so it required the feed-water to be very cold, as he had found from his own observation.

For attaining the same object as an exhaust-steam injector, but without using one at all, an apparatus of his own invention, which was simply an addition to the ordinary injector, had the advantage, while giving about the same economical results, that the ordinary injector with which it was connected worked quite independently of it; if there was any exhaust steam, the injector returned a considerable portion of it to the boiler; but if there did not happen to be any exhaust steam, the injector went on working just the same as if the apparatus were not there at all. In Fig. 9, Plate 23, A was the delivery pipe from an ordinary injector, $B$ was the ordinary clackbox, and at $C$ the delivery pipe had about 8 inches cut out of it, and the apparatus he referred to was inserted; its lower flange $\mathbf{D}$ was 
connected with a branch pipe $\mathbf{D}$ E from the exhaust of the engine, and in connection with its lower branch was a back-pressure valve opening inwards. Fig. 10 was an enlarged sectional view of the apparatus, and its action was obvious; $F$ was a contracted nozzle, like the ond of the combining cone in an ordinary injector; $G$ was similar to the receiving throat in an ordinary injector; and the interval between $F$ and $G$ represented generally the overflow portion of an ordinary injector; also $G \mathrm{~K}$ was the ordinary delivery cone for gradually converting velocity into pressure. As the current rushed from $F$ to $G$, the exhaust steam entering through the back-pressure valve $H$ was condensed; and while the lateral or inductive action of the jet carried it onwards into the boiler, the temperature of the jet itself was simultaneously raised. The secret of the whole action lay not only in the proportion which the areas $F$ and $G$ bore to each other and to the throat of the injector, but also in the fact that an injector would force against a considerably higher pressure than the steam which worked it, so that a sufficient excess of pressure would be got at $F$ for overcoming and penetrating the boiler-pressure at $G$. The back-pressure valve $H$ prevented any water from escaping into the exhaust while the injector was being started. As the natural temperature of feed-water in England was about $56^{\circ} \mathrm{F}$., or say $60^{\circ} \mathrm{F}$. to be on the safe side for summer weather, and as the water was generally raised in every-day working $60^{\circ} \mathrm{F}$. in its passage through the injector, it followed that there was $212^{\circ}-120^{\circ}=92^{\circ}$ which might be added to the temperature of the feed by this apparatus; or as the last $12^{\circ}$ was rather difficult to attain, say $200^{\circ}-120^{\circ}=80^{\circ}$, representing an absolute gain of $80^{\circ} \mathrm{F}$. on all the water evaporated in the boiler. The above was a practical calculation, and gave a result easy of attainment; and a practical way of testing the efficacy of this apparatus was to put one hand on the water-pipe leading to it, and the other hand on the delivery-pipe leading from it, when the difference would be found to be very striking.

Another method of his for dealing with exhaust steam was represented in Fig. 11, Plate 23, and was for returning exhaust steam into a boiler at any pressure, high or low, and without the aid of any live steam under any cireumstances whatever. As 
however in its present form it required plenty of cooling water, it could be used only for marine or land engines, and not always for the latter. A was a water nozzle, through which water rushed with nearly the velocity due to the pressure in the boiler, the effluent water having been led from a closed ressel, connected by a pipe with the water space of the boiler, through a long series of cooling coils or pipes, while the cooling water of course flowed in the reverse direction. The water jet then projected itself through the steam nozzles $\mathrm{B}, \mathrm{C}$, and $\mathrm{D}$, against the throat $\mathrm{E}$, where it encountered its own original pressure; naturally it could not enter Lere unaided, but in its course it had been assisted or had had a series of "kicks up" given to it by the exhaust steam entering at G, and so was enabled to penetrate the resistance at $\mathbf{E}$, and through the usual diverging nozzle $F$ to re-enter the closed vessel intermediate between the jet apparatus and the boiler. The exhaust steam assisted it in the following way:- the steam in the immediate neighbourhood of the jet was condensed; to fill up the local vacuum, more steam at once rushed in at a high velocity, and being directed by the shape of the nozzles $B, C$, and $D$ into almost the same direction as the jet itself, it thereby accelerated the jet to such an extent as to enable it to penetrate at $\mathrm{E}$. The action in this instrument resembled to a certain extent what took place in an ordinary injector, namely condensation, acceleration, and concentration; but it differed in this way, that the water, instead of having to be started from a state of rest, had already a certain momentum in it, and therefore required but little acceleration from the exhaust steam; and also the water jet was in the centre, instead of being an annular jet as in most injectors. The apparatus might almost be described as a combination of a surface condenser and a Morton's ejector condenser, with the advantages of both and the disadvantages of neither. No air-pump was required; and the same water being used over and over again, no scale was deposited except what fell from the small quantity of fresh water that was introduced. The action was continuous, water continually flowing at boiler pressure from the closed vessel in connection with the boiler, becoming cooled, passing through the instrument, taking up as much exhaust steam on its way 
as it could condense, becoming accelerated in doing so, and then re-entering at a high temperature the closed vessel with the exhaust steam it had taken up, to go through the same process again as long as the engine was at work. The object of the closed vessel intermediate between the jet apparatus and the boiler was to economise the heat that was represented by the difference between the temperature of the heated water delivered from the jet apparatus and the boiler temperature; which difference, at $60 \mathrm{lbs}$. boiler pressure, was about $100^{\circ} \mathrm{F}$. All that actually re-entered the boiler was an amount of water equal in weight to the condensed exhanst steam; and all the rest of the water returned direct to the jet apparatus through the cooler, withont having been heated up to boiler temperature.

In the exhaust-steam injector described in the paper the leading and only now feature was the split nozzle with the hinged flap; and he asked what would be the effect of any solid substance getting under the hinge. It was all very well to say that if the injector stopped it would at once set about starting again; but if anything hard out of the feed-water did get under the hinge, the instrument would do nothing but stop and try to start again, and instead of doing any work would merely keep on "dithering." Nevertheless it was ingenious, though the principle of the idea was by no means new; for he had himself tested and worked, about fourteen years ago, an injector invented by Mr. Körting of Vienna, in which the combining cone was made in two parts, but divided transversely at such a point that the area where it was separated was greater than the area of the steam nozzle. When the injector had got up its penetrating velocity, the extra or first overflow was shut off from the air by turning a stopcock, and the injector was at work; but of course, though it answered the same purpose, it was not automatic; in this point only was it inferior, for it had all the other advantages of the injector described in the paper. If however it were decided to have an automatic injector, let it be a substantial one, in which there was more power to overcome obstacles; for this purpose its closing action should be dependent on the powerful boiler-pressure, and not on a comparatively weak, uncertain, and only partial vacuum. Such an 
instrument was shown in Fig. 12, Plate 23. It looked like an ordinary injector, but internally it had two overflow spaces-the ordinary one at $\mathbf{A}$, and an extra and temporary one at $B$. The temporary one was for the purpose of starting the injector, and its area was somewhat greater than that of the steam nozzle C. Its action was as follows:- - the steam issuing at $C$ rushed through $B$ and A, forming a vacuum in the water space, into which up rushed the water; and the water being driven forwards by the steam and creating a pressure at $D$, the combining nozzle $D$ A B was then forced up, the overflow at $B$ was firmly closed, and the injector was at work. Here the moveable combining nozzle resembled to a certain extent the moveable nozzles in the injectors of Mr. Sellere and of Messrs. Robinson and Gresham, but was of course for a totally different purpose. This injector would work with either live or exhaust steam or both together; it could be placed either above or below the feed-water, and was perfectly automatic; it had however to be placed vertically, so that the combining nozzle $D A$ should fall whenever the action stopped, and so be ready to start again. The particular injector shown in Fig. 12 was arranged to be worked by live steam from a high-pressure boiler, and to be placed either above or below the level of the feed-water. For working with exhaust, the steam and water nozzles would require to be differently proportioned; and except as regarded the starting, there was really no difference whatever between an exhaust and a live-steam injector, beyond the relative sizes of the working parts.

It might be mentioned that, up to the time of the invention of the exhaust-steam injector, the most that had been done in that direction had consisted-either in introducing exhaust steam into the overflow of the ordinary injector: which was bad, because the overflow should always be free, and indeed most drivers liked to be able to hear it;-or in having a central exhaust nozzle inside the jet of livo steam: which was also bad, because when air got in with the exhaust it was of course not condensed with the steam in the combining cone, but merely compressed into globules, which burst the jet at the overflow space and stopped the injector. In addition those injectors were difficult to start, and when started were liable to 
stop; and when stopped they required an attendant to start them again. Hence the demand for automatic exhaust-steam injectors.

Mr. W. Steele Tomkins, having had to do with the manufacture of the exhaust-steam injector when it was first brought out, said it was very interesting as an entirely new application of the principle of the injector; it was also clearly a source of great economy, opening a very wide field for saving. He had been very much struck when he first saw it working on a locomotive against $120 \mathrm{lbs}$. pressure, with exhaust steam only; but it must be confessed that in that particular engine the back pressure was greater than usual. It was not stated in the paper, but it might be taken to be the fact, which no doubt the author would clearly confirm, that the back pressure in the cylinders when exhaust injectors were working was of course reduced. With regard to the economy, he would not anticipate what the author would have to say, except by remarking that as compared with any feed-water heater there was this difference: that the feed-water heater might be doing its best at all times, but the injector must be doing its best at all times. There was no question that the economy which it professed to give was obtained. What that would be, he would leave the author to explain. On locomotives as well as on stationary engines the exhaust-steam injectors were already working in some considerable numbers. It was quite true that the application was not so simple as in the case of the live-stcam injector; but for all that, the economy obtained was perfectly uninterfered with. With regard to the injector with the sliding nozzle divided transversely, which had been described by Mr. Sharp, the same idea had occurred to himself in Manchester some time ago; but he thought it ought to be said that the results hitherto had not been quite so good as had been anticipated, and at all events were not yet worth mentioning.

Mr. Chardes Cochrane was sure that, if there was any difficulty in explaining how steam at high pressure could feed its own boiler, the diffeulty was intensified when it came to exhaust steam doing the same. He had applied the exhaust-steam injector at the Woodside 
Iron Works, Dudley; and had entered upon the experiment with great misgiving as to its success, though he was comforted by the thought that others had been before him, and that there need be no risk. He had been astonished to see the way in which exhaust steam from an engine would, while relieving the engine during the time of feeding the boiler, supply the boiler itself. But while the exhaust-steam injector, when applied where there was only cold water available for feeding the boilers, was invaluable for warming the cold water up to the highest point possible during the time of feeding, he would call attention to the fact that this warming took place during only a few minutes. The injector was so rapid in its action that the boiler was fed up full in a few minutes, less or more; and during the whole of the rest of the time the exhaust steam was escaping from the engine without doing any work whatever. The benefit of the exhaust-steam injector was great in the way of delivering hot water into the boiler, but the economy be thought was not much, because of the shortness of the time during which the feeding was taking place; the short time so occupied was trifling compared with the length of time during which the exhaust steam was escaping unused into the atmosphere.

Mr. Peter D. Bennetr said he had three or four of the automatic exhaust-steam injectors at work at the Horseley Iron Works, Tipton. The difficulty started by Mr. Cochrane was got over by putting in an ordinary throttle-valve between the exhaust-steam pipe and the injector, and by opening the valve only far enough to admit as much exhaust steam as would just keep the feed-water continuously going into the boiler. By that means the cold feed-water was regularly heated up to probably between $160^{\circ}$ and $170^{\circ}$. He regarded the exhaust-steam injector as one of the most ingenious contrivances he had ever met with; and the three or four he had at work were acting in the most perfect manner. They had simply been put on the boilers, and the connection made to the vertical exhaust-pipe by means of a horizontal pipe with an ordinary throttle-valve inserted for regulating the admission of the exhaust steam; and the injector then went on working in the most perfectly automatic way conceivable. 
The invention he considered was one that ought to be generally known; and if known he believed it would be generally used.

Mr. Jayrs Greshan said that, Mr. Sharp having anticipated most of what he had beon about to say, he would only add that he looked upon the invention of the exhaust-steam injector as one of the greatest steps in the last quarter of a century. Having himself been connected with injectors for rather more than that length of time, he considered the only great improvement that had been made upon them was this of working with exhaust steam, which he believed dated back at least eleven years. The instrument represcnted in Fig. 12, Plate 23, with combining-nozzle divided transversely and sliding vertically, nearly illustrated an injector which he should have sketched himself if Mr. Sharp had not done so; and he believed it was one that would work as well as that with the flap nozzle, when designed as some had been that were still working; but it would not work with exhaust steam without a much larger steam-nozzle. He had much pleasure in testifying to what he considered the excellence of the injector described in the paper, and be thought that great credit was due to those who had first been bold enough to think that exhaust steam could be used at all. He was certainly anxious, as others had been, to hear some scientific explanation of the working of the exhaust-steam injector, both theoretically and practically, which did not seem to have been clearly set forth.

Mr. Druite Haspin thought the easiest way of looking at the action of the injector, and at the seeming impossibility of an injector with steam of atmospheric pressure delivering water into boilers at a higher pressure, was to regard it purely as a thermodynamic question. It could be reasoned out by changes of velocity; but the easiest way was to look at it as a question of a certain amount of steam-either exhaust steam or steam of any pressure whateverwhich was at a certain temperature, and contained a certain number of thermal units: that steam simply did a certain amount of work, in lifting water up to a certain level, and then forcing it into the boiler. Mr. Sharp had remarked that the only waste that took place 
was by radiation. Radiation was no doubt one source of waste; but allowance should also be made for the heat converted into mechanical work in performing the work of feeding the boiler itself.

Mr. JAMES G. DAw thought that, from what they had now heard with regard to the practical working of the exhaust-steam injector, every one must be deeply interested with the novelty of the invention. But what was now required was to consider its utility. It had been mentioned by Mr. Bennett that cold feed-water was heated by the injector up to between $160^{\circ}$ and $170^{\circ}$. With an ordinary feed-water heater worked by the feed-ram he had raised cold water up to $212^{\circ}$ before putting it into the boiler, measuring the temperature by a very thin copper plug, which was inserted into the feed-pipe and was connected with a sensitive thermometer outside. Mr. Cochrane had spoken of the injector being very rapid in its action; and probably that would give some difficulty to the engineman. He should be glad to hear something more concerning the actual advantage of the exhaust-stcam injector as applied to boilers; if there was no clear advantage, he should be somewhat cautious before introducing it for feeding boilers.

Mr. James Plate said his firm had one of the exhaust-steam injectors, and had perhaps used it under very unfavourable circumstances. The boiler was at a distance of some 60 feet from the engine; the exhaust steam passed through six bends, and there was no throttle-valve in the exhaust pipe; there was simply a connection from the exhaust pipe to the injector at the bottom of the first bend nearest the cylinder. The injector worked exceedingly well, being of the proper size for the boiler, so that it was continuously at work, with the consequent advantage of saving the maximum heat out of the exhaust steam during the whole time; it answered all the purposes for which it was intended. But a diffeulty had been found from the water containing a considerable quantity of carbonate of lime and some other substances, and from part of the grease from the cylinder being carried into the boiler, which had occasioned a good deal of trouble, producing a bulging of the 
furnace plates. With the exception of that difficulty the injector had answered all their expectations; and it was really an admirable invention.

Mr. Wirltam Anderson pointed out that the theory of the action of the injector had been explained, a considerable number of years ago, both by the late Sir William Siemens and also by Sir Frederick Bramwell, in connection with papers* read before this Institution by Mr. Robinson and before the Institution of Civil Engineers by Mr. England. The explanations they had given were remarkable for their simplicity and lucidity, showing how it was that the injector, acting with steam at a lower pressure, would even put water into a boiler at $a$ higher pressure. In the use of exhaust steam for foeding a boiler at $75 \mathrm{lbs}$., the difference of pressure might be rather greater than that alluded to in those explanations; but the principle was the same.

Mr. William Sogönheyder agreed with previous speakers that, in addition to the saving of heat by the use of the exhaust-steam injector, there was also a saving of feed-water. Of course there was a considerable proportion of feed-water put into the boiler in the shape of exhaust steam, he thought about 15 per cent.; so that, where feed-water was scarce, this was an advantago; and it was clean water.

Mr. James B. Alumotr said that somo little time ago his firm had had experiments conducted with reference to the exhaust-steam injector, with the special object of testing the exact increase in the temperature of the feed-water, and also the increase in the quantity of it from the addition of the condensed steam. In regard to both points the results varied very much with the quantity of water that was being fed through the injector. With a small feed the

* Proceedings Institution of Mechanical Engineers, 1860, pp. 48-50, and 78 ; 1861, p. 227 ; and 1866 , p. 274.

Proceedings Institution of Civil Engineers, 1865, vol. xxiv., pp. 222, 228, 236. 
temperature of the water was much more increased than with a large feed. Of course as the temperature was increased, so also the proportion increased of condensed stenm which mixed with the feed. With a large feed there was an increase in quantity of between 14 and 15 per cent., and an increase in temperature of between $76^{\circ}$ and $78^{\circ}$. With a small feed there was an increase in quantity of 21 per cent. and in temperature of $122^{\circ}$ or $123^{\circ}$. Obviously in some instances the increase in the quantity of feed-water would be a matter of some importance; but in all cases the increase in temperature was of course a matter of very considerable economy. An injector which made use of exhaust steam alone, for the purpose of feeding a boiler, he thought was not capable of application to all boilers or under all circumstances; but the number of instances in which such an injector was applicable was very large, and wherever it could be applied its advantages were obvious.

The hinged flap which formed a portion of the split nozzle in the automatic injector had been spoken of as a part that might be expected to be troublesome and delicate in its action. At his own works boilers had been fed with one of the injectors for the last two years and eight months; and by way of testimony from actual experience the nozzle and flap of that injector. were now exhibited, and he thought it would be found on examination that they had not suffered from their working during that period. He was not aware of any instance in which any foreign matter had found its way into the flap and stopped the action of the injector; yet he could not say that his feed-water was of a very fine quality or that it was free from impurity.

Mr. SavilL, replying to the comment which had been made on the need of live steam for feeding boilers at higher pressures than 75 lbs., said the paper had not dealt with the application of the exhaust-steam injector to locomotives, as that subject was of sufficient importance to be dealt with in a separate paper. The exhaust injector heated the feed-water up to $190^{\circ}$ and gave it a pressure of $75 \mathrm{lbs}$; then it wanted a fillip to carry it into a locomotive boiler at $150 \mathrm{lbs}$. pressure. This additional impulse was given by a separate smaller 
or supplementary injector, worked by the boiler steam, and so proportioned as to take feed-water of $190^{\circ}$ or any higher temperature, and force it into the boiler. The steam taken from the boiler to work this supplementary injector of course heated the water additionally, and was returned into the boiler. Supposing the exhaust stenm alone had been sufficient to enable the water to penetrate into a boiler of $150 \mathrm{lbs}$. pressure, the water so forced in would have a temperature of say $190^{\circ}$; and when it got into the boiler it would have to mingle at once with water of over $360^{\circ}$. But if by using steam from the boiler the feed-water conld be heated up to say over $280^{\circ}$, there could be nothing lost, because whatever steam was taken from the boiler for working the supplementary injector was returned into the boiler again in the feed-water, while at the same time the water would be heated nearer the temperature of the water in the boiler, which would be admitted to be an advantage and not a disadvantage.

Of the contrivances described by Mr. Sharp, some had been experimented with at the Atlas Works, Manchester, several years ago, and as mentioned by Mr. Tomkins they had not been found to be practically of much value. It was true they had worked with exhaust steam and fed a boiler up to 70 lbs. pressure; but then they took so long to start, and they were so delicate in starting, not being automatic, that practically they would be no good for ordinary use. What was wanted was something quite antomatic, that did not require starting at all, but would start of itself; and the flap of the split nozzle did that undoubtedly, as known from actual experience. He had himself tested nozzles similar to those shown in Figs. 11 and 12, Plate 23; but they had been practically no good, for the reasons above stated.

With regard to Mr. Sharp's scheme for using an ordinary injector and then heating the feed-water by means of exhanst steam after it had left the ordinary injector, that was beginning at the wrong end; what was wanted was to heat the feed-water with exhaust steam when it was cold, so as to get the full benefit of the exhaust steam; and then the heating could be carried on higher with the boiler steam afterwards. Taking the natural temperature of the feed-water as $60^{\circ}$, Mr. 
Sharp had added $60^{\circ}$ as the heating which would occur in an ordinary injector supplied with steam enough to give the requisite power for forcing the water into the boiler. For locomotives perhaps the $120^{\circ}$ so arrived at was a little under-estimated; in fact in an injector supplied with steam at 60 lbs. pressure it would be found that about $160^{\circ}$ was the temperature to which the feed-water was raised. But taking it at the low figure of $120^{\circ}$, it had been stated that the feed-water could then be heated up by exhaust steam afterwards to $200^{\circ}$ as a minimum. That was an addition of only $80^{\circ}$ due to the exhaust steam; but with the exhaust injector, taking in water at $60^{\circ}$ and heating it up to $190^{\circ}$, the addition amounted to $130^{\circ}$. In the case of a locomotive runuing at a quick speed wit was found that the temperature went up not only to $190^{\circ}$ but even to $208^{\circ}$, with the exhaust injector alone; in that case, owing to the high speed, the injector had had good hot dry steam to do the work. As to the exhaust injector not being available for locomotives, he was glad to say that a large number were working on locomotives, and giving every satisfaction. In fact the above figures were from actual locomotive practice, and showed a very marked difference from the arrangement described by $\mathrm{Mr}$. Sharp; the latter was estimated to deliver water into a locomotive boiler at $200^{\circ}$ when using both boiler and exhaust steam, whilst the exhaust injector delivered it at over $270^{\circ}$ under the same conditions.

The injector brought out some years ago by Mr. Körting was admitted by Mr. Sharp to have been practically a failure; and therefore no more need be said about it now.

The injector working on the principle of a piston, sketched in Fig. 12, Plate 23, was very similar to the self-adjusting injector of Mr. Sellers, which had been thought at one time to be a great improvement; but in actual practice it had been found not to work well, as the piston was liable to stick; and very few of those injectors were at work in England at the present time. If one of them were tried with such water as was used by Mr. Alliott at Nottinghnm, he was persuaded it would fur up.

The economy of the exhaust-steam injector was certainly one of the most important points in connection with its use. When, as 
was often the case, a live-steam injector had been uscd prior to the introduction of the exhaust-steam injector, both of them taking their feed-water at its natural temperature, an advantage was found in economy of fuel, with stationary engines, of never less than 20 per cent. and often of more, in favour of the exhaust injector. In feed-water heaters, the percentage of economy varied considerably; and a feed-water heater was a very good thing as long as it was big enough, but a very large heater was required to do a small amount of work.

Mr. Cochrane understood the statement that the economy in fuel with the exhaust-steam injector was 20 per cent. greater than the economy with an injector worked by high-pressure steam; but he should be glad to know what was the absolute saving by the former, because it had been spoken of as about 15 per cent., that being according to Mr. Schönheyder the proportion of feedwater returned into the boiler in the shape of exhaust steam.

Mr. Savinu could not give the absolute saving by the exhauststeam injector, because he did not know the actual economy shown by an ordinary live-steam injector over a pump; but he thought this could not be very great in respect of fuel. No doubt there was a great economy in an ordinary injector over pumps; but it was not so much in fuel, because the loss in the pump was only from friction; the chief economy of the injector over the pump was in respect of wear and tear. The exhaust injector, showing an economy of 20 per cent. over a live-steam injector in the fuel alone, showed 25 per cent. economy ho believed over a pump pumping cold water into the boiler.

Mr. Cochrane asked whether the question might not be answered if put in this way: how much of the exhaust steam was got back into the boiler?

Mr. Savitu replied that of course that would depend upon whether the boiler was merely supplying steam for the engine, and 
for nothing else; in which case from one-fifth to one-sixth of the exhaust steam was taken back into the boiler by the injector.

Mr. Cochrane thought that proportion would about correspond with the increase which had been mentioned of the feed-water temperature from $50^{\circ}$ to $190^{\circ}$, an increase of $140^{\circ}$.

Mr. Savilu believed those figures would be found to be not far wrong as a fair average; isolated cases could be picked out that were a great deal better, and others that were worse. The economy in the quantity of feed-water used might be taken roughly at about 15 per cent.; it was difficult to tell exactly what it was, because in very few boilers was the water measured. Some elaborate experiments had been made last October at Nottingham* by Messrs. Manlove Alliott Fryer \& Co., which showed 15 per cent. saving in quantity of feed-water, and an increase of $1 \frac{1}{2} \mathrm{lb}$. of water evaporated per lb. of coal, in farour of the exhaust-steam injector over a feed-pump.

The Presidenc observed that the increase in the temperature of the feed-water would give the exact quantity.

Mr. CooHrane said that was what he had been looking at, and his own calculations on that basis led him to agree with the author that one-seventh was about the quantity of feed-water that could be saved.

Mr. Savilu explained that the reason of the injector at Mr. Cochrane's works filling up the boiler at once, and then having to stop for an hour, was simply that the size of the injector was too large for the boiler. He always objected to putting on an injector too large for the boiler, because it was better to keep the injector constantly going; it should be just a little larger than required for the maximum work, but not too large.

* See Engineering, 18th April, 1884, pp. 339-310. 
Another respect in which the exhaust-steam injoctor differed from an ordinary live-steam injector was that when it was working it acted beneficially on the engine piston, especially if there was a little back pressure, as it had the effect of diminishing the back pressure of the exhaust steam.

Respecting the wear and tear of the hinged nozzle, he exhibited the nozzles of three injectors, and also one complete injector, in order to show what effect constant use had had on them. All had been working for over two years, and it would be seen that they were practically as good as when new, nothing whatever having been done to them except wiping them with a sponge cloth, so as to show the surfaces up. The first nozzle was from a No. 8 injector of the locomotive type, which had been working in Manchester. The second was the nozzle of a No. 7 injector, kindly brought by $\mathrm{Mr}$. Alliott, which as stated by him had been working with Nottingham water for two years and eight months; and it would be admitted that it was but little the worse for so doing, although the water was none of the best, but rather the reverse. The third nozzle had been taken that vory evening from a No. 4 injector working with London water, and had not even been cleaned for over six months. The complete injector was a No. 4, which had been working in Manchester for more than $2 \frac{1}{2}$ years. The excellent condition of all these hinged nozzles was a proof both of their durability, and also that the fear lest something hard might happen to get under the hinge was not realised in practice, otherwise the metal would show marlss of the occurrence. It was indeed impossible for anything to get under the hinge, because anything that could pass the large opening at the hinge would be free to pass completely through the nozzle, while anything too large to pass through the opening could never reach the hinge.

The question of grease getting introdueed into the boiler along: with the exhaust steam was one that depended entirely upon the way in which the branch exhaust-pipe going to the injector was led off from the main exhaust pipe. If the branch was to be taken off from a vertical main pipe, the connection should be made at right angles, as shown in Fig. 4, Plate 21 ; and if from a horizontal main 
pipe, then the branch must be taken from the top side of the pipe, because if it were led off from the bottom the grease would undoubtedly run into the branch pipe and be carried into the boiler; but when the branch was connected on the top of the horizontal exhaust-main, he had found that practically no grcase at all was carried into the boiler. No trouble from grease had been experienced in any of the boilers on which the injectors now exhibited had been working, the branch-pipe connections being made in conformity with these recommendations. The trouble experienced by Mr. Platt had arisen from the fact of the branch exhaust-pipe having been in that case led off vertically downwards from the lower side of an elbow at the bottom of the main vertical exhaust-pipe; the branch pipe formed therefore a trap, into which the grease running down the sides of the vertical exhaust-main. would collect; and the exhaust steam flowing to the injector would carry the grease along with it, and deliver it into the boiler. Had the branch to the injector been taken off higher up from the vertical exhaust main, there would have been no trouble from the grease. Notwithstanding the number of exhaust injectors now working, both in this country and abroad, under almost every conceivable condition, he had had up to the present time only one other complaint respecting grease, besides that now mentioned; and in both cases the trouble was traced to the wrong manner in which the branch exhaust-pipe was connected to the main exhaust-pipe.

The Prasident was sure the Members would all agree with him in thanking the author of the paper for having brought before them what, until it had been seen, would be regarded as an almost incredible mode of feeding a boiler. 
Fig. 1. Ordinary

Lifting

Injector.

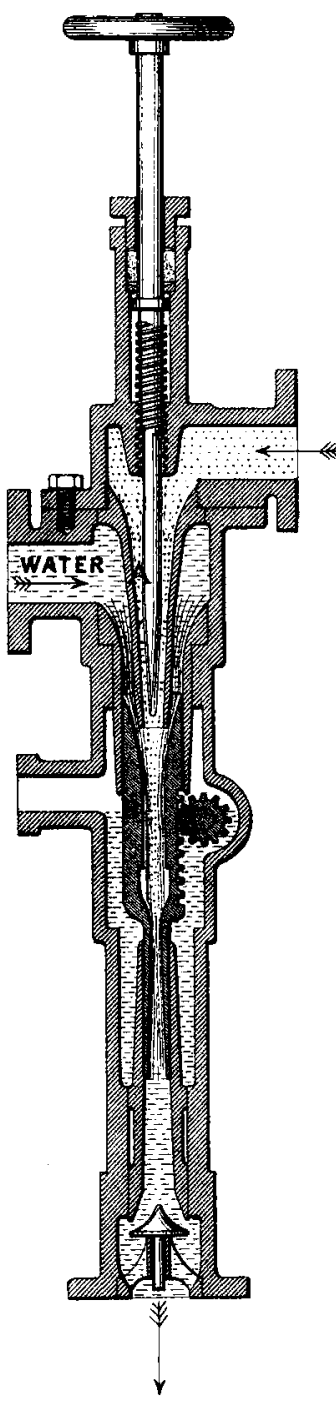

STEAM

Fig. 2 . Automatic Re-starting Injector:

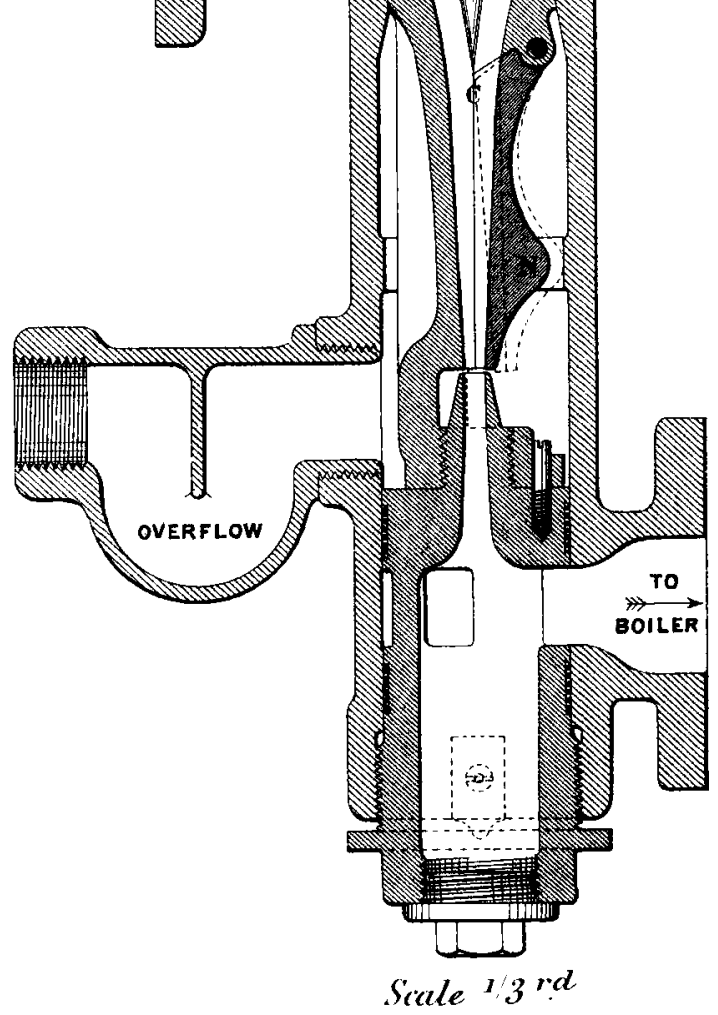

Srale $1 / 0^{\text {th }}$ Sicale ${ }^{1 / 3} \cdot d$ 
AUTOMATIC INJECTOR.

Plate:21.

Fig. 3. Split Nozzle in Live-Steam Injector.
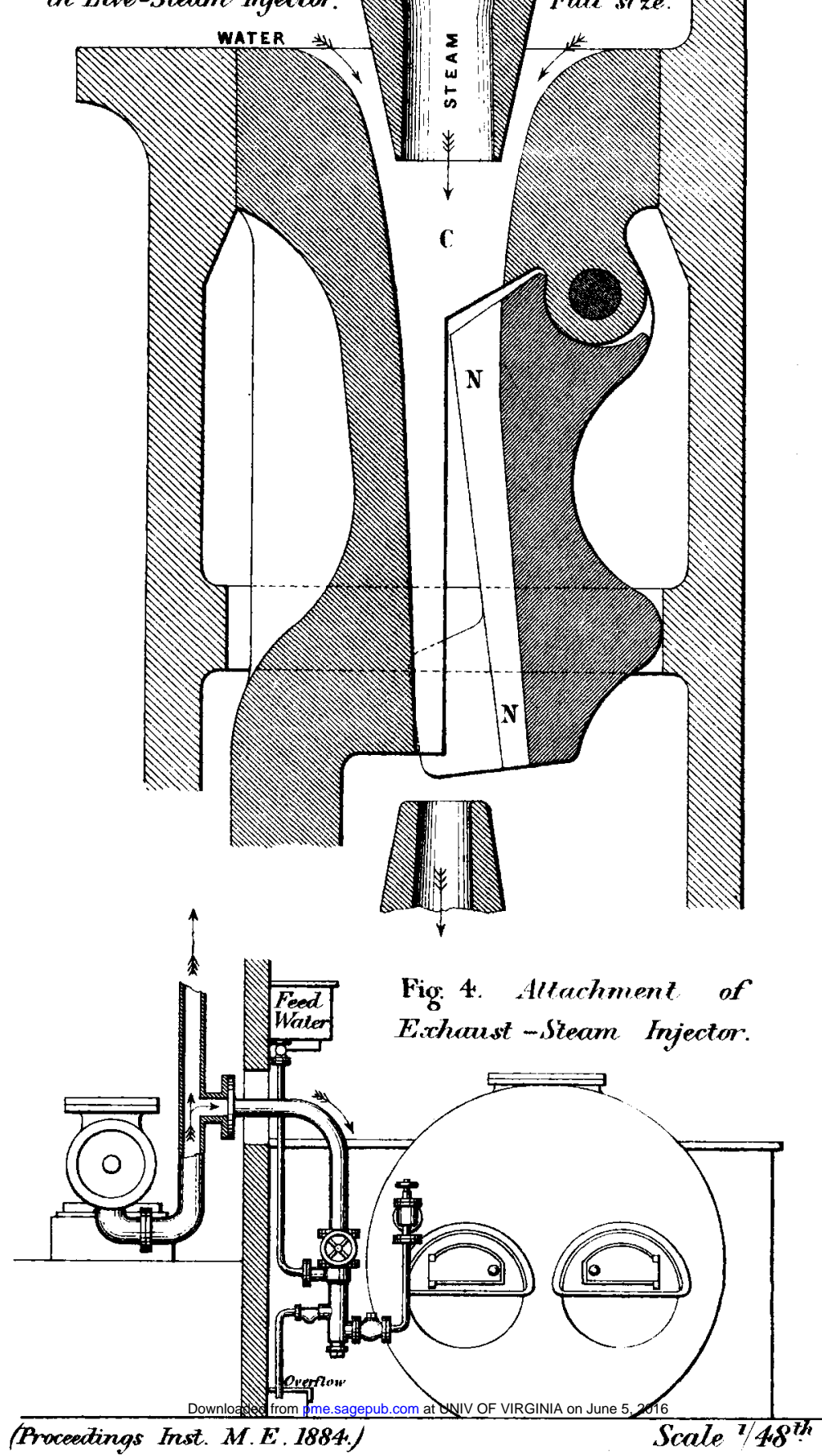


\section{AUTOMATIC INJECTOR. Plate 29.}

Spliz Nozile in Exhanst-Steam Fyjector.

\section{Longiludinat Sections.}

Fig. 5. Flap open.

Fig. 7. Flap shait.
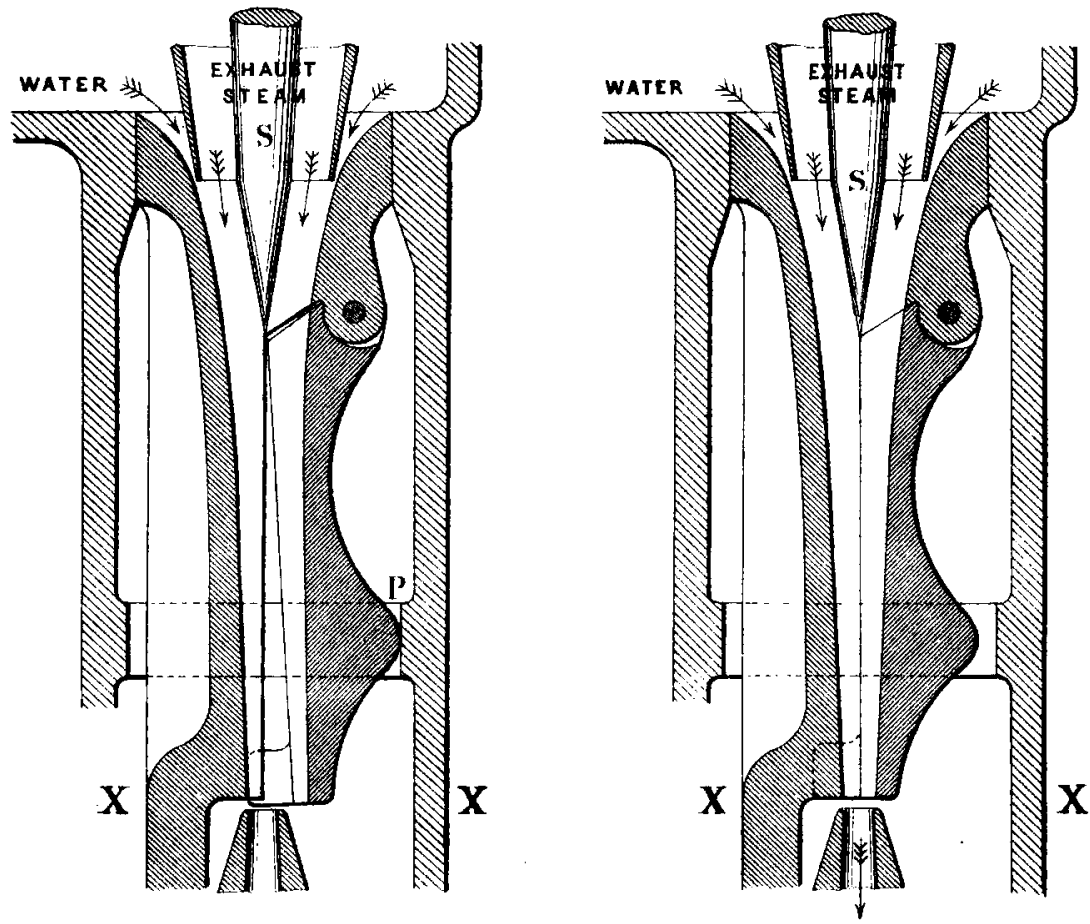

Fig. 6. Fronsverse Sections Fig. 8.

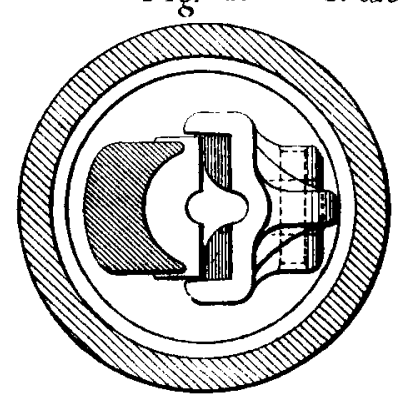

(inverted) at XX.

Scale half fill size.

Downloaded from pme.sagepub.com at UNIV OF VIRGINIA on June 5, 2016 
EXHAUST - STEAM INJECTOR.
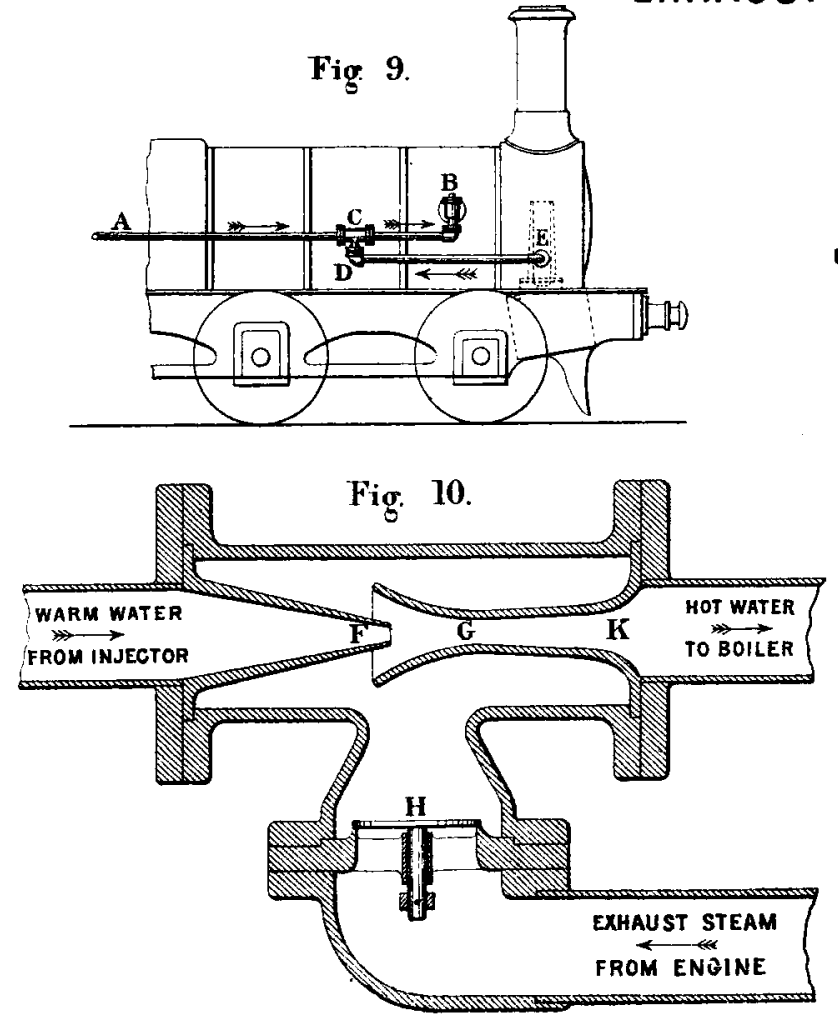

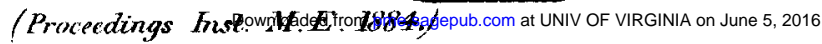
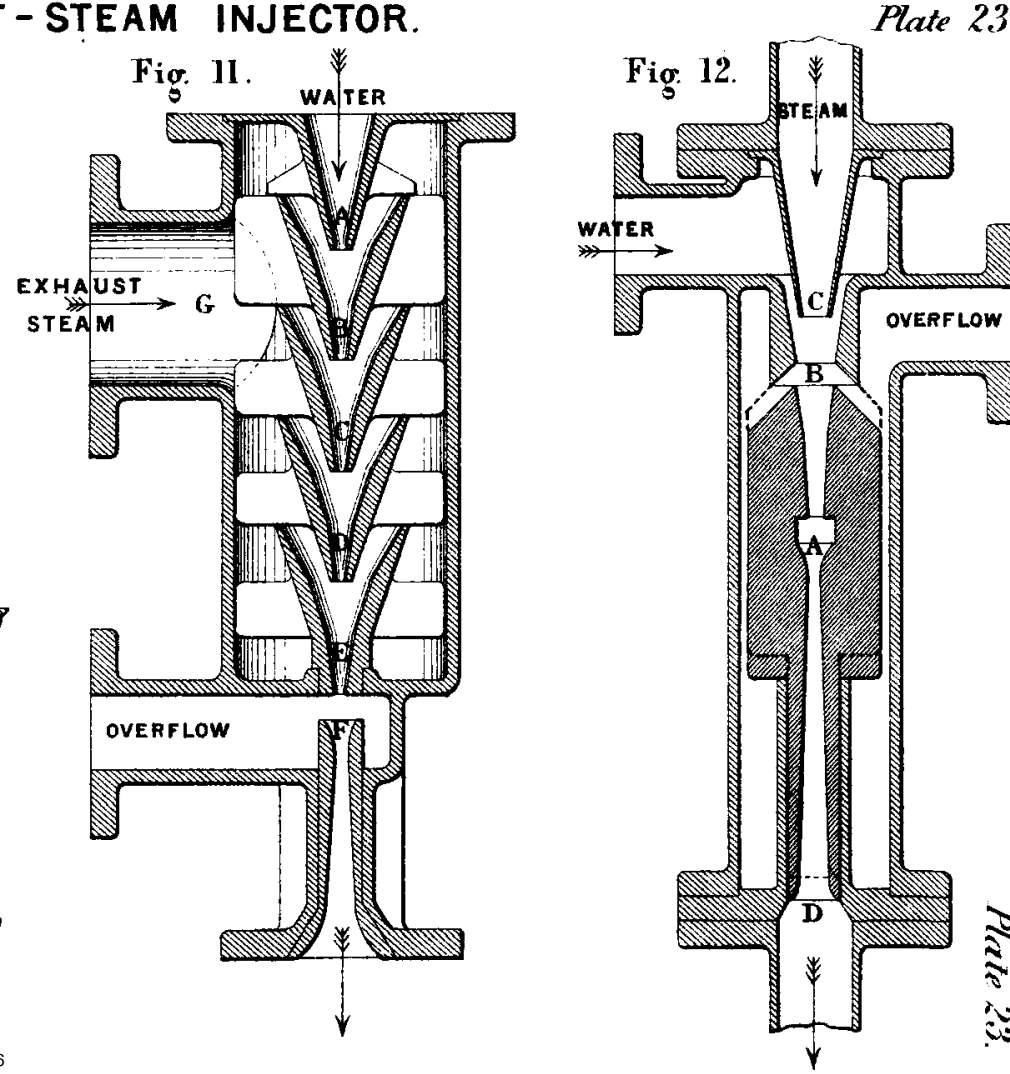